\title{
ANALISIS PENGELOLAAN BARANG MILIK DAERAH MENURUT PERATURAN PEMERINTAH NOMOR 27 TAHUN 2014 PADA PEMERINTAH KABUPATEN MINAHASA SELATAN
}

\author{
Ariel Rorimpandey, Grace B. Nangoy, Hendrik Manossoh \\ (e-mail : arielrorimpandey@gmail.com)
}

\begin{abstract}
Local assets has important role and function for South Minahasa Regency Government to support the wheels of government and public service. The purpose of this study was to analize the suitability of local assets management in South Minahasa Regency Government to Government Regulation No. 27 Year 2014. This study was conducted at The Local Agency Of Finance, Revenue And Assets Management In South Minahasa Regency. Local assets management based on Government Regulation No. 27 Year 2014 include requirements planning and budgeting, procurement, use, utilization, security and maintenance, assessment, transfer, destruction, disposal, administration, and guidance, supervision and control. This study is a qualitative descriptive research. The informant was determined by using purposive sampling method. Data analysis was performed with data reduction, data display and conclusion. The results showed basically, the local assets management has been cultivated implemented based on PP No. 27 year 2014, although there are obstacles in implementing local assets management such as the lack of regulation in regency such as local asset management regulation under PP No. 27 year 2014, lack of knowledge and understanding of human resources and lack of leadership commitment of SKPD in local asset management.
\end{abstract}

Keywords : Local assets management, government regulation, local assets

\section{PENDAHULUAN}

Perubahan yang terjadi dalam sistem pemerintahan di Indonesia merupakan suatu upaya dalam rangka mewujudkan good governance dan peningkatan pelayanan kepada masyarakat guna terwujudnya masyarakat yang sejahtera. UUD 1945 mengamanatkan adanya hubungan keuangan, pelayanan umum serta pemanfaatan sumber daya alam dan sumber daya lainnya antara Pemerintah Pusat dan Pemerintah Daerah diatur dan dilaksanakan secara adil dan selaras berdasarkan Undang-Undang. Berlakunya UU (Undang-Undang) No. 23 Tahun 2014 tentang pemerintahan daerah membuat penyelenggaraan pemerintahan daerah diarahkan untuk mewujudkan kesejahteraan masyarakat melalui peningkatan pelayanan, pemberdayaan, peran serta masyarakat dan peningkatan daya saing dengan memperhatikan prinsip demokrasi, pemerataan, keadilan dan kekhasan suatu daerah. Oleh karena hal-hal tersebut, pemerintah daerah membutuhkan barang-barang yang akan menunjang jalannya semua urusan pemerintahan.

Permasalahan yang sering terjadi pada pemerintah daerah dalam pengelolaan barang milik daerah adalah belum diterapkan secara benar aturan pengelolaan barang milik daerah yang berakibat pada pengadaan barang yang belum sesuai dengan tugas pokok dan fungsi SKPD, penggunaan barang milik daerah yang tidak sesuai penetapan penggunaan, barangbarang rusak dan usang hanya dibiarkan begitu saja belum, belum lengkap administrasi aset daerah sehingga rawan hilang dan dicuri, barang-barang yang dibiarkan dan tidak terpelihara diambil alih pihak lain, laporan administrasi barang milik daerah oleh SKPD sering terlambat, barang yang tidak dikembalikan ke SKPD oleh pejabat yang telah pensiun, rendahnya kinerja pengurus dan penyimpan barang milik daerah untuk menjaga dan merawat barang milik daerah ditambah lagi aparatur daerah yang kurang berkompetensi. 
Barang milik daerah mutlak menjadi perhatian serius bagi pemerintah daerah. Hal ini tidaklah berlebihan mengingat pengelolaan barang milik daerah memberikan dampak bagi jalannya roda pemerintahan, pelayanan kepada masyarakat dan salah satu dasar dalam pemberian opini oleh BPK. Rumusan masalah dalam penelitian ini adalah bagaimana pengelolaan barang milik daerah menurut PP No. 27 Tahun 2014 pada Pemerintah Kabupaten Minahasa Selatan. Tujuan penelitian ini adalah untuk menganalisis kesesuaian pengelolaan barang milik daerah Kabupaten Minahasa Selatan dengan Peraturan Pemerintah No. 27 Tahun 2014 di Kabupaten Minahasa Selatan. Bagi Pemerintah Kabupaten Minahasa Selatan diharapkan penelitian ini dapat memberikan sumbangan pemikiran dalam mengambil keputusan/ kebijakan mengenai pengelolaan barang milik daerah Kabupaten Minahasa Selatan Bagi dunia pendidikan, diharapkan dapat bermanfaat bagi perkembangan ilmu yang berkaitan dengan masalah pengelolaan barang milik daerah dan memperkuat teori-teori yang telah berkembang sebelumnya, serta sebagai referensi terhadap jenis penelitian yang sama.

\section{TINJAUAN PUSTAKA}

\section{Teori Keagenan}

Dalam teori keagenan Jensen dan Meckling (1976), hubungan keagenan merupakan suatu kontrak dimana satu orang atau lebih (principal) memerintah orang lain (agent) untuk melakukan suatu jasa atas nama prinsipal serta memberi wewenang kepada agen untuk membuat keputusan.

\section{Logistik}

Menurut Kusumastuti (2014) peran logistik dalam organisasi publik sangat berhubungan erat dengan penyelenggaraan fungsi pemerintahan di daerah baik secara langsung maupun tidak langsung..

\section{Good Governance}

Menurut UNDP (1997) dikutip Lukow (2013) menyatakan Konsep Good Governances sebagai proses penyelenggaraan kekuasaan negara dalam melaksanakan penyediaan public goods and service disebut governance (pemerintah atau kepemerintahan), sedangkan praktik terbaiknya disebut good governance (kepemerintahan yang baik).

\section{Barang Publik}

Menurut Pyndick (1996) dikutip Iskandar (2013) barang publik adalah barang yang dapat diproduksi dengan murah untuk konsumen, tetapi sekali barang tersebut diproduksi maka sulit melarang orang lain untuk menggunakannya.

\section{Implementasi Kebijakan}

Faktor-faktor dalam implementasi kebijakan menurut Edwards III (1980) dikutip Juanda (2011) antara lain Komunikasi, Sumber daya, Disposisi/kecenderungan-kecenderungan atau tingkah laku, Struktur birokrasi.

\section{Akuntansi Sektor Publik}

Menurut Mardiasmo (2000) dikutip Hasfi (2013) akuntabilitas publik yang harus dipenuhi dalam rangka pengelolaan barang milik daerah adalah akuntabilitas kejujuran dan akuntabilitas hukum, akuntabilitas proses, akuntabilitas kebijakan

\section{Pengelolaan Barang Milik Daerah}

Pengelolaan barang milik daerah sesuai PP No 27 Tahun 2014 meliputi perencanaan kebutuhan dan penganggaran; pengadaan; penggunaan; pemanfaatan; pengamanan dan pemeliharaan; penilaian; pemindahtanganan; pemusnahan; penghapusan; penatausahaan; dan pembinaan, pengawasan, dan pengendalian.

\section{Asas Pengelolaan Barang Milik Daerah}

Pengelolaan barang milik daerah dilaksanakan dengan berdasarkan pada asas pengelolaan barang milik daerah (Chabib Sholeh dan Heru Rochmansjah, 2010 dan Darise 2009) seperti asas fungsional, kepastian hukum, transparansi, efisiensi, akuntabilitas dan kepastian nilai. 


\section{Barang Milik Daerah}

Barang milik daerah dalam Peraturan pemerintah No. 27 tahun 2014 disusun menurut perkiraan neraca yang terdiri dari aset lancar, aset tetap dan aset lainnya.

\section{Laporan Keuangan Pemerintah Daerah}

Pengelolaan barang milik daerah tentu pada akhirnya akan menghasilkan laporan barang milik daerah. Laporan barang milik daerah yang dihasilkan akan digunakan sebagai dasar dalam penyusunan neraca daerah. Dalam Peraturan Pemerintah Republik Indonesia Nomor 71 Tahun 2010, Neraca menggambarkan posisi keuangan suatu entitas pelaporan mengenai aset, kewajiban, dan ekuitas pada tanggal tertentu.

\section{Penelitian Terdahulu}

Penelitian menyangkut barang milik daerah telah dilakukan beberapa peneliti diantaranya penelitian yang dilakukan oleh Hasfi (2013) dan Priyono (2013). Hasfi (2013) meneliti tentang pengelolaan barang milik daerah Pada Dinas Pendapatan, Pengelolaan Keuangan dan Aset Kabupaten Sintang dan hasilnya menunjukkan bahwa, pengelolaan barang milik daerah pada DPPKA Kabupaten Sintang belum sepenuhnya terlaksana dengan baik dan tidak sesuai prosedur yang diatur dalam PP No. 6 Tahun 2006 tentang pengelolaan barang milik daerah dihadapkan beberapa kendala dibidang organisasi, sumber daya aparatur, aturan dan praktek manajemen pengelolaan barang yang belum sesuai dengan aturan yang ada. Sedangkan Priyono (2013) yang meneliti keandalan informasi laporan keuangan daerah berbasis akrual (kajian pengelolaan aset tetap daerah kabupaten sampang) menunjukkan bahwa pengelolaan barang milik daerah Kabupaten Sampang belum dilaksanakan secara memadai menurut PP No. 6 Tahun 2006. Berdasarkan penerapan asas-asas pengelolaan barang milik daerah dan selanjutnya dikaitkan dengan karakteristik keandalan informasi, maka disimpulkan bahwa penyajian informasi aset tetap daerah pada Pemerintah Kabupaten Sampang belum andal.

\section{Kerangka Konseptual}

Pengelolaan barang milik daerah harus dilakukan secara professional, tertib, akuntabel dan transparan guna menunjang pelaksanaan tugas pemerintahan. Barang milik daerah mutlak menjadi perhatian serius bagi pemerintah daerah. Pengelolaan barang milik daerah menurut PP No. 27 Tahun 2014 meliputi perencanaan kebutuhan dan penganggaran; pengadaan; penggunaan; pemanfaatan; pengamanan dan pemeliharaan; penilaian; pemindahtanganan; pemusnahan; penghapusan; penatausahaan; dan pembinaan, pengawasan, dan pengendalian.

\section{METODE PENELITIAN}

\section{Jenis Penelitian}

Pendekatan kualitatif digunakan untuk dapat menggali informasi secara utuh dari sumber informasi dan data dinyatakan dalam keadaan yang sewajarnya untuk membuat deskripsi, gambaran secara sistematis, faktual, dan akurat mengenai pengelolaan barang milik daerah pada Pemerintah Kabupaten Minahas Selatan. Penelitian kualitatif ini menggunakan metode deskriptif

\section{Jenis dan Sumber Data}

Sumber data yang digunakan pada penelitian ini adalah sebagai berikut, yaitu data primer, yaitu data yang diperoleh dengan melakukan wawancara kepada informan kunci dan data sekunder. Sumber data peneliti dalam penelitian ini adalah kata-kata dan tindakan informan. Sumber data lainnya dari Peraturan Pemerintah, buku, jurnal, modul, koran dan yang terkait dalam pengelolaan barang milik daerah. 


\section{Lokasi dan Waktu Penelitian}

Penelitian ini mengambil lokasi di DPPKA Kabupaten Minahasa Selatan. Penelitian pengelolaan barang milik daerah dibatasi sampai tahun anggaran 2015 yang telah diperiksa oleh BPK.

\section{Prosedur Pengumpulan Data}

Sugiyono (2014) menyatakan bahwa dalam penelitian kualitatif, teknik pengumpulan data dapat dilakukan dengan observasi, wawancara dan studi dokumentasi.

\section{Informan Penelitian}

Dalam menentukan informan penelitian ini, peneliti menggunakan Purposive sampling. Informan kunci yang ditetapkan oleh peneliti berjumlah 4 (empat) orang yaitu Kepala Bidang Aset, Kepala Seksi Pengelolaan Aset, Kepala Seksi Analisa Aset, Kepala Seksi Inventaris aset dan informan biasa yakni admin 1 dan admin 2 Simda-BMD Dinas Pengelola Keuangan, Pendapatan dan Aset Daerah.

\section{Teknik Analisis Data}

Aktivitas dalam analisis data yaitu data reduction, data display dan conclusion drawing (Sugiono, 2014).

\section{HASIL ANALISIS DAN PEMBAHASAN Gambaran Umum Objek Penelitian}

Berdasarkan PP No. 27 Tahun 2014, maka Bupati adalah pemegang kekuasaan pengelolaan barang milik daerah dibantu oleh Sekda sebagai Pengelola barang milik daerah. Sebagai Pembantu Pengelola barang milik daerah di Kabupaten Minahasa Selatan adalah PPKD (Pejabat Pengelola Keuangan Daerah) yaitu Kepala Dinas Pengelola Keuangan, Pendapatan dan Aset Daerah. Untuk dapat menjalankan tugas dan fungsi dalam pengelolaan barang milik daerah seperti yang telah diamanatkan, maka pengelolaan barang milik daerah yang dipimpin oleh Kepala Dinas Pengelola Keuangan, Pendapatan dan Aset daerah membawahi Bidang Aset dengan dibantu oleh Seksi Pengelolaan Aset, Seksi Inventarisir Aset, Seksi Analisa. Kepala SKPD adalah pengguna barang milik daerah dibantu oleh Pengurus Barang, Penyimpan Barang dan Atasan Langsung Pengurus Barang.

Dinas Pengelola Keuangan, Pendapatan dan Aset Daerah memiliki sifat yang khas, karena Kepala Dinas Pengelola Keuangan, Pendapatan dan Aset Daerah bertindak sebagai Kepala SKPKD dan SKPD. Sesuai dengan Perda No. 4 Tahun 2009 tentang Pengelolaan Barang Milik Daerah di Kabupaten Minahasa Selatan maka Dinas Pengelola Keuangan, Pendapatan dan Aset Daerah mempunyai tugas dan fungsi mengkoordinir penyelenggaraan pengelolaan barang milik daerah pada SKPD.

\section{Hasil Penelitian}

Pelaksanaan pengelolaan barang milik daerah pada Pemerintah Kabupaten Minahasa Selatan menurut hasil wawancara didasarkan pada PP No. 27 Tahun 2014 Tentang Pengelolaan Barang Milik Daerah dan Perda No. 4 Tahun 2009 Tentang Pengelolaan Barang Milik Daerah Di Kabupaten Minahasa Selatan yang disadur dari PP No. 6 Tahun 2006 Tentang Pengelolaan Barang Milik Daerah dan peraturan pelaksanaannya yakni Permendagri No. 17 Tahun 2007 Tentang Pedoman Teknis Pengelolaan Barang Milik Daerah.

\section{Pembahasan}

\section{Perencanaan Kebutuhan dan Penganggaran}

Tahapan dalam perencanaan kebutuhan barang milik daerah menurut hasil penelitian pada dasarnya telah dilaksanakan, namun oleh SKPD dokumen perencanaan tidak dihimpunkan ke Bidang Aset, sehingga tugas dan fungsi dari Bidang Aset untuk mengkoordinasikan penyusunan rencana kebutuhan barang untuk ditetapkan oleh Pengelola 
Barang menjadi rencana kebutuhan barang milik daerah tidak terlaksana. Penerapan kebijakan pengelolaan barang milik daerah memerlukan kerja sama antara pihak-pihak yang terkait dengan pengelolaan barang milik daerah. Oleh karena itu, dibutuhkan komunikasi yang baik antara pihak-pihak tersebut. Komunikasi dalam organisasi merupakan suatu proses yang amat kompleks dan rumit (Edwards III, 1980 dalam Juanda, 2011).

\section{Pengadaan}

Pengadaan barang milik daerah merupakan proses yang panjang dan rumit sehingga membutuhkan penjelasan lebih detail dalam peraturan yang secara khusus mengatur mekanisme pengadaan yakni Perpres No. 70 Tahun 2012 tentang Pengadaan Barang/Jasa Pemerintah. Mardiasmo (2000) dikutip Hasfi (2013) menyatakan bahwa pengelolaan barang harus memenuhi akuntabilitas proses terkait dengan dipatuhinya prosedur yang digunakan dalam melaksanakan pengelolaan kekayaan daerah, termasuk didalamya dilakukan compulsory competitive tendering contract (CCTC) dan penghapusan mark-up. Untuk itu perlu kecukupan sistem informasi akuntansi, sistem informasi manajemen, dan prosedur administrasi.

\section{Penggunaan}

Penetapan status penggunaan oleh Pemerintah Kabupaten Minahasa Selatan dilakukan sebagai upaya penegasan pemakaian barang milik daerah dalam rangka tertib pengelolaan barang dan kepastian hak, wewenang dan tanggungjawab kepada SKPD. Penetapan status penggunaan berdasarkan dari usulan SKPD ke pengelola barang melalui Bidang Aset yang nantinya diterbitkan SK Penggunaan.

Penetapan status pengunaan dilakukan agar barang milik daerah mendapat pengamanan, tidak disalahgunakan, mudah dilakukan pengawasan dan dapat dipertanggungjawabkan penggunaannya. Hal ini mendukung studi Juanda (2011) bahwa prinsip good governance yaitu akuntabilitas.

\section{Pemanfaatan}

Pemanfaatan barang milik daerah yang dilakukan Pemerintah Kabupaten Minahasa Selatan sebagai upaya untuk mendayagunakan barang milik daerah yang tidak digunakan untuk penyelenggaraan tugas dan fungsi SKPD serta untuk optimalisasi barang milik daerah dengan tidak mengubah status kepemilikannya. Mardiasmo (2000) dikutip Hasfi (2013) menyatakan bahwa prinsip akuntabilitas publik harus dipenuhi dalam rangka pengelolaan barang milik daerah. Akuntabilitas publik yang harus dipenuhi terkait dengan akuntabilitas kejujuran dan akuntabilitas hukum.

\section{Pengamanan dan Pemeliharaan}

Pengamanan terhadap barang milik daerah oleh Pemerintah Kabupaten Minahasa Selatan sebagai tindakan yang harus dilakukan oleh Pengelola, Pembantu Pengelola, Pengguna agar barang milik daerah terjaga dan dalam keadaan aman sehingga jumlah, kondisi, dan keberadaan barang tersebut sesuai dengan yang tercatat di administrasi.

Pemeliharaan terhadap barang milik daerah Pemerintah Kabupaten Minahasa Selatan dapat menambah masa manfaat atau menambah nilai barang. Pengamanan dan pemeliharaan barang milik daerah menurut apa yang diungkapkan oleh Darise (2009) merupakan tindakan pengendalian dalam pengurusan barang milik daerah dalam bentuk fisik, administratif dan tindakan upaya hukum, sedangkan pemeliharaan adalah suatu rangkaian kegiatan untuk menjaga kondisi dan memperbaiki semua barang milik daerah agar selalu dalam keadaan baik dan siap digunakan secara berdaya guna dan berhasil guna.

\section{Penilaian}

Nilai aset yang disajikan dalam neraca daerah merupakan nilai historis/nilai buku, sehingga diperlukan penilaian kembali atas aset untuk mendapatkan nilai wajar meiputi seluruh aset yang dimiliki Pemerintah Kabupaten Minahasa Selatan. Penilaian yang dilaksanakan Pemerintah Kabupaten Minahasa Selatan dilakukan oleh KPKNL dalam 
pengelolaan barang milik daerah sebagai upaya untuk mendukung kepastian nilai dengan adanya ketepatan jumlah dan nilai barang. Hasil ini mendukung studi yang dilakukan Simamora (2012) yang menyatakan bahwa penilaian merupakan suatu proses kegiatan penelitian yang selektif didasarkan pada data/fakta yang objektif dan relevan dengan menggunakan metode/teknik tertentu untuk memperoleh nilai barang milik daerah.

\section{Pemindahtanganan}

Pemindahtanganan barang milik daerah yang dilakukan Pemerintah Kabupaten Minahasa Selatan dilakukan melalui penjualan, tukar menukar, hibah, penyertaan modal. Pemindahtanganan dilakukan terhadap barang yang sudah tidak diperlukan lagi dan sudah tidak dapat digunakan dalam pelaksanaan tugas pemerintahan setelah sebelumnya ditentukan nilainya dalam penilaian barang milik daerah. Chabib Sholeh dan Heru Rochmansjah (2010) serta Darise (2009) menyebutkan bahwa pemindahtanganan barang milik daerah berdasarkan asas kepastian nilai yaitu adanya ketepatan jumlah dan nilai barang yang akan dilakukan pemindahtanganan.

\section{Pemusnahan}

Pemusnahan barang dapat dilakukan terhadap barang yang sudah tidak dapat dimanfaatkan lagi, kadaluarsa atau tidak dapat dipindahtangankan dalam hal ini rusak dan yang jikalau harus dijual maka biaya yang timbul untuk penjualan akan lebih besar dari manfaat ekonomi yang di dapat. Penelitian ini mendukung hasil penelitian Tukunang (2016) bahwa pemusnahan dilakukan karena tidak laku dijual, rusak, kadaluwarsa, membahayakan kepentingan umum, atau karena ketentuan peraturan perundangan yang mengharuskan untuk dimusnahkan.

\section{Penghapusan}

Penghapusan barang milik daerah oleh Pemerintah Kabupaten Minahasa Selatan yang dilakukan melalui Bidang Aset sebagai tindakan membebaskan SKPD dari tanggung jawab penguasaan terhadap barang milik daerah secara fisik dan secara administrasi dengan menghapus dari daftar barang milik daerah. Subagya (1995) mendefinisikan penghapusan sebagai kegiatan dan usaha-usaha pembebasan barang dari pertanggungjawaban sesuai peraturan atau perundang-undangan yang berlaku. Penghapusan barang milik daerah yang dilakukan Bidang Aset meliputi penghapusan dari daftar barang pengguna atau SKPD dan dari daftar barang milik daerah Pemerintah Kabupaten Minahasa Selatan.

\section{Penatausahaan}

Proses penatausahaan yang dikoordinasikan Bidang Aset sudah menggunakan aplikasi simda-BMD, dimana SKPD langung melakukan input data ke Simda-BMD menurut perkiraan neraca yang terdiri dari aset lancar, aset tetap dan aset lainnya. Penatausahaan barang milik daerah harus memenuhi akuntabilitas publik yang menurut Rahman (2000) dikutip Lukow (2013) merupakan prinsip yang menjamin bahwa setiap kegiatan penyelenggaraan pemerintahan dapat dipertanggungjawabkan secara terbuka oleh pelaku kepada pihak-pihak yang terkena dampak penerapan kebijakan. Pertanggungjawaban barang milik daerah melalui laporan keuangan daerah khususnya didalam neraca daerah sering terhambat sebagai akibat dari SKPD yang terlambat dalam menyampaikan laporan barang milik daerah ke Bidang Aset.

\section{Pembinaan, pengawasan dan pengendalian}

Pembinaan yang dilakukan Pemerintah Kabupaten Minahasa Selatan melalui Bidang Aset dilakukan dengan pemberian pedoman, bimbingan, pelatihan, dan supervisi untuk menjamin kelancaran penyelenggaraan pengelolaan barang milik daerah. Dalam pembinaan pengelolaan barang, bimbingan sangat diperlukan karena pedoman tertulis masih bisa menimbulkan perbedaan persepsi dari Kepala SKPD, pengurus dan penyimpan barang. Pengawasan dan pengendalian merupakan dua hal yang tidak dapat dipisahkan dari proses 
pengelolaan barang milik daerah Pemerintah Kabupaten Minahasa Selatan, hal ini dimulai sejak dari perencanaan sampai kepada pelaporan.

\section{Hambatan Pengelolaan Barang Milik Daerah}

Dalam penelitian ini ditemukan 3 faktor yang menghambat pengelolaan barang milik daerah yaitu sumber daya manusia, Regulasi di daerah, Komitmen pimpinan.

\section{KESIMPULAN DAN SARAN \\ Kesimpulan}

1. Pada dasarnya, pengelolaan barang milik daerah telah diusahakan dilaksanakan sesuai dengan aturan yang berlaku, walaupun ada hambatan dalam melaksanakan pengelolaan barang milik daerah seperti belum adanya regulasi di daerah berupa Perda pengelolaan barang berdasarkan PP 27 Tahun 2014, keterbatasan pengetahuan dan pemahaman sumber daya manusia dan kurangnya komitmen pimpinan SKPD dalam pengelolaan barang milik daerah;

2. Perencanaan barang milik daerah Pemerintah Kabupaten Minahasa Selatan terhambat oleh karena tidak dimasukkannya data perencanaan setiap SKPD yang diminta Bidang Aset untuk dihimpun menjadi rencana kebutuhan barang milik daerah. Rencana kebutuhan barang yang tidak dihimpunkan ke Bidang Aset bukan berarti perencanaan tidak dibuat SKPD, tapi sebagai dampak peralihan peraturan pengelolaan barang milik daerah ke aturan yang terbaru. Pertanggungjawaban barang milik daerah melalui laporan keuangan daerah khususnya didalam neraca daerah sering terhambat sebagai akibat dari SKPD yang terlambat dalam menyampaikan laporan barang milik daerah ke Bidang Aset. Proses-proses pengelolaan barang milik daerah yang lainnya sesuai tahapan telah berjalan baik

\section{Saran}

1. Perlu segera menetapkan Perda pengelolaan barang milik daerah yang berpedoman pada PP No. 27 Tahun 2014 dan Permendagri 19 Tahun 2016 yang baru diterbitkan Pemerintah sehingga pelaksanaan pengelolaan barang milik daerah di Kabupaten Minahasa Selatan mendapat kepastian hukum;

2. Pemerintah Kabupaten Minahasa selatan perlu menetapkan standar operasional prosedur pengelolaan barang untuk memudahkan pemberian tugas dan tanggungjawab, memudahkan pemahaman pengelolaan barang milik daerah, mempermudah dalam mengetahui terjadinya kegagalan sistem dan penyelewengan kewenangan, memudahkan dalam kontrol ketepatan waktu pelaporan dan monitoring;

3. Pemerintah Kabupaten Minahasa Selatan perlu mengadakan sosialisasi, bimbingan dan pelatihan teknis bagi kepala SKPD, pengurus dan penyimpan barang milik daerah untuk meningkatkan komitmen, pemahaman dan kapasitas mereka dalam melakukan pengelolaan barang milik daerah;

4. Pemerintah Kabupaten Minahasa Selatan perlu menetapkan pengendalian dan pengawasan yang meliputi seluruh tahap dalam pengelolaan barang milik daerah. Pengendalian dan pengawasan dilakukan oleh pejabat yang memang memiliki kapasitas dalam pengendalian dan pengawasan barang milik daerah.

\section{DAFTAR PUSTAKA}

Azhar, Iqlima. 2013. Pengaruh Kualitas Aparatur Daerah, Regulasi, Dan Sistem Informasi Terhadap Manajemen Aset (Studi Pada SKPD Pemerintah Kota Banda Aceh). Pascasarjana Universitas Syiah Kuala. Jurnal Akuntansi Volume 2, No.1 ISSN 23020164. 
Basir, Abd. 2009. Analisis Faktor-Faktor Yang Mempengaruhi Kapasitas Fiskal Daerah Kota Parepare. Program Studi Magister Keuangan Daerah. Program Pasca Sarjana Universitas Hasanuddin Makassar.

Bungin, B. 2003. Analisis Data Penelitian Kualitatif : Pemahaman Filosofis dan Metodologis Ke Arah Penguasaan Model Aplikasi. Jakarta : Raja Grafindo Persada

Chabib Soleh dan Heru Rocmansjah. 2010. Pengelolaan Keuangan dan Aset Daerah. Jakarta : Fokus Media

Crhistine, Amela E. 2014. Perbandingan PP 27 Tahun 2014 Tentang Pengelolaan Barang Milik Negara/Daerah dengan PP 6 Tahun 2006 dan PP 38 Tahun 2008. Sekolah Tinggi Akuntansi Negara.

Darise, Nurlan. 2009. Pengelolaan Keuangan Daerah. Jakarta : PT Indeks

Direktorat Jenderal Perimbangan Keuangan. 2014. Pengelolaan Barang Milik Daerah. Kementerian Keuangan Republik Indonesia.

Hanis, Muhammad H. 2011. The Aplication Of Public Asset Mangement In Indonesian Local Government (Case Study In South Sulawesi Province). Queensland University Of Technology, Brisbane Australia. Jurnal Of Corporate Real Estate Vol. 13 No.1, 2011 PP, 36-47 DOI : 10.1108/14630011111120332

Hasfi, Nyemas. 2013. Pengelolaan Barang Milik Daerah (Suatu Studi Pada Dinas Pendapatan, Pengelolaan Keuangan dan Aset Kabupaten Sintang). Magister Ilmu Sosial Fakultas Ilmu Sosial dan Ilmu Politik Universitas Tanjungpura Pontianak. Jurnal Tesis PMIS UNTAN PSIAN Vol.1, No 0001.

http://beritakawanua.com/berita/minsel/sudah-dua-minggu-server-e-ktp-rusak-di-minselrusak\#sthash.aUSJWuaf.dpbs di akses tanggal 24 Juni 2016

http://manado.bpk.go.id/

http://www.detikawanua.com/2016/05/fasilitas-umum-di-minsel-memprihtinkan.html?m=1 di akses tanggal 24 Juni 2016

http://www.gomanado.com/2016/07/19/13911/banyak-gedung-sekolah-rusak-di-minselmamoto-input-dapodik-sekolah-kurang-perhatikan-fasilitas-sekolah/ di akses tanggal 19 Agustus 2016

http://www.identitasnews.com/2016/04/gara-gaar -jalan-lengan-wartawati.html? $\mathrm{m}=1 \mathrm{di}$ akses tanggal 24 Juni 2016

http://www.manadoterkini.com/2015/10/18581/pemkab-minsel-gelar-bimtek-penelusuranbmd-bagi-pejabat-dan-pegawai-pengelola/ di akses tanggal 28 Desember 2015

http://www.manadoterkini.com/2016/06/33757/wow-ternyata-inilah-penyebab-minsel-gagalraih-wtp/ di akses tanggal 14 Juli 2016

http://www.manadoterkini.com/2016/09/37258/Wabup-Minsel-cek-keberadaan-aset-di-tigadinas/ di akses tanggal 26 September 2016

http://www.mediasulut.co/detailpost/waspadai-penggelapan-aset-daerah di akses tanggal 26 September 2016

Iskandar, Ika A. 2013. Analisis pengadaan barang/jasa di Pemerintah Kota Sukabumi, Pemerintah Kota Bogor dan Lembaga Kebijakan Pengadaan Barang/Jasa Pemerintah (LKPP). Fakultas Ekonomi Program Studi Mgister Perencanaan dan Kebijakan Publik Universitas Indonesia.

Istianto, Bambang. 2009. Manajemen Pemerintahan Dalam Perspektif Pelayanan Publik. Jakarta : Mitra Wacana Media

Jensen, M dan W. Meckling. 1976. Theory of the Firm : manegerial behavior, Agency and Ownership Stucture Journal Of Financial Economic.University Of Rochester. Journal of Financial Economics, October, 1976, V. 3, No. 4, pp. 305-360 
Juanda. 2011. Implementasi Good Governance Dalam Proses Transfer Aset Pemerintah Daerah Kota Metro. Fakultas ISIP Prodi Magister Ilmu Pemerintahan. Universitas Lampung

Kusen, Gaby Jelly. 2015. Prinsip-Prinsip Hukum Pengelolaan Aset Daerah (Studi Pada Pemerintah Provinsi Sulawesi Utara). Pascasarjana Universitas Sam Ratulangi. Lex et societatis, vol. III/no. 2/mar/2015/edisi khusus

Kusumastuti, Dyah. 2014. Modul Manajemen Logistic Organisasi Publik. Tangerang Selatan : Universitas Terbuka.

Lembaga Administrasi Negara dan Badan Pengawasan Keuangan dan Pembangunan. 2000. Akuntabilitas Dan Good Goverenance. Jakarta Lembaga Admnistrasi Negara dan Badan Pengawas Keuangan dan Pembangunan,.

Local Governance Support Program, Finance and Budgeting Team. 2008. Panduan Pelatihan Pengelolaan Barang Daerah dan Penyusunan Rencana Pengelolaan BMD (Barang Milik Daerah). LGSP

Lukow, Seftian. 2013. Eksistensi Good Governance Dalam Sistem Pemerintahan Daerah Di Kota Manado. Program Studi Ilmu Hukum Pascasarjana Universitas Sam Ratulangi. Vol.I/No.5/Oktober-Desember /2013

Mahmudi. 2010. Manajemen Keuangan Daerah. Jakarta : Erlangga

Mardiasmo. 2009. Akuntansi Sektor Publik. Yogyakarta : Andi.

Masdiantini, Putu Riesty. 2016. Pengaruh Ukuran Pemerintah Daerah, Kemakmuran, Intergovernmental Revenue, Temuan dan Opini Audit BPK Pada Kinerja Keuangan. Fakultas Ekonomi dan Bisnis Universitas Udayana Bali. E-Jurnal Akuntansi Universitas Udayana 14.2 Februari 2016. 1150-1182. ISSN 2302-8556

Moleong, Lexy J. 2000. Metodologi Penelitian Kualitatif. Bandung : PT. Remaja Rosdakarya Nadir, S. 2014 . Modul Mata Kuliah Kebijakan Publik. Universitas Hasanudin

Nagor, Teuku Fahrian. 2015. Pengaruh Penerapan Sistem Pengendalian Intern dan Penerapan Prinsip Pengelolaan Keuangan Daerah Terhadap Kualitas Laporan Keuangan Pemerintah Daerah Kabupaten Aceh Barat (Studi Pada SKPD Pemerintah Daerah Kabupaten Aceh Barat). Magister Akuntansi Pascasarjana Universitas Syiah Kuala Banda Aceh. Jurnal Magister Akuntansi Pascasarjana Universitas Syiah Kuala Volume 4, No. 1, Februari 2015 ISSN 2302-0164 pp 72-79.

Nordiawan, deddi dan Ayuningtyas Hertianti. 2010. Akuntansi Sektor Publik Edisi Kedua. Jakarta : Salemba Empat

Pekei, Beni. 2014. The Effectiveness Of Local Asset Management (A Study On The Government Of Jayapura). Faculty of Economics and Business, Brawijaya University Malang, East Java, Indonesia. International Journal of Business and Management Invention ISSN (Online): 2319 - 8028, ISSN (Print): 2319 - 801X www.ijbmi.org Volume 3 Issue 3\| March. 2014\| PP.16-26.

Ponamon, Irene Fransisca. 2014. Pengaruh Pengawasan Internal, Pemahaman Sistem Akuntansi Keuangan, dan Kapasitas Sumber Daya Manusia Terhadap Kualitas Informasi Laporan Keuangan Pemerintah Daerah Pada SKPD Pemerintah Kota Manado. Fakultas Ekonomi dan Bisnis Universitas Sam Ratulangi. Jurnal Going Concern Vol. 9 No. 2 ISSN 1907-9737

Priyono, Karnanto. 2013. Keandalan Informasi Laporan Keuangan Daerah Berbasis Akrual : Kajian Pengelolaan Aset Tetap Daerah Kabupaten Sampang. UIN Malang. Jurnal Akuntansi Vol. 4 No. 1 E-ISSN : 2442-8922

Pusdiklat Kekayaan Negara dan Perimbangan keuangan. 2010. Pemanfaatan Barang Milik Daerah. Departemen Keuangan Republik Indonesia

Republik Indonesia. 2014. Undang-Undang No. 23 Tahun 2014 tentang Pemerintahan Daerah. 
Republik Indonesia. 2010. Peraturan Pemerintah No. 71 Tahun 2010 tentang Standar Akuntansi Pemerintahan. Sekretariat Negara RI.

Republik Indonesia. 2014. Peraturan Pemerintah No. 27 Tahun 2014 tentang Pengelolaan Barang Milik Negara/Daerah. Sekretariat Negara RI.

Republik Indonesia. 2012. Peraturan Presiden No. 70 Tahun 2012 tentang Pengadaan Barang/Jasa Pemerintah. Sekretariat Negara RI.

Republik Indonesia. 2007. Peraturan Menteri Dalam Negeri No. 17 Tahun 2007 tentang Pedoman Teknis Pengelolaan Barang Milik Daerah. Sekretariat Negara RI.

Sambudi. 2012. Implementasi Pengelolaan Barang Milik Negara di Pengadilan Tinggi Agama Manado. Program Studi PSP Pascasarjana Unsrat. Jurnal Ilmu administrasi (JIA) Vol 8, No. 3 (2012)

Simamora, Rudianto. 2012. Faktor-faktor yang mempengaruhi pengelolaan aset pasca Pemekaran wilayah dan pengaruhnya terhadap kualitas laporan Keuangan pemerintah di kab. Tapanuli selatan. Magister Sains Akuntansi Fakultas Ekonomika \& Bisnis UGM Yogyakarta. Jurnal Ekonomi dan Bisnis. Volume 10 Nomor 01.

Subagya. 1995. Manajemen Logistik. Jakarta : PT. Gunung Agung

Sugiyono. 2014. Memahami Penelitian Kualitatif. Bandung : CV. Alfabeta

Sumampow, Nancy. 2015. Implementasi Kebijakan Pengelolaan Barang Milik Daerah Pada Dinas Pendidikan, Pemuda dan Olah Raga Kabupaten Sigi. Program Studi Magister Administrasi Publik Pascasarjana Universitas Tadulako. e-Jurnal Katalogis, Volume 3 Nomor 2, Pebruari 2015 ISSN: 2302-2019

Suparmoko. 2001. Ekonomi Publik Untuk Keuangan Dan Pembangunan Daerah, Penerbit Andi, Yogyakarta.

Sutawa. 2014. Pengaruh Pengembangan Sumber Daya Manusia Terhadap Pengelolaan Aset Dan Kinerja Pada Dinas Pendapatan, Pengelolaan Keuangan Dan Aset Kabupaten Ngawi. Fakultas Ekonomi Universitas Soerjo Ngawi. MEDIA SOERJO Vol. 14 No 1 April 2014. ISSN 1978 - 6239

Suteja, I Made Agus. 2016. Implementasi Dokumen Pelaksanaan Anggaran Sebagai Bagian Laporan Pertanggungjawaban Pada Akuntabilitas Publik dan Transparansi Pemerintah Kabupaten Badung-Bali. Fakultas Ekonomi dan Bisnis Universitas Udayana, Bali, Indonesia.E-Jurnal Ekonomi dan Bisnis Universitas Udayana 5.1(2016) :1-28 ISSN:2337-3067.

Suwanda, Dadang. 2013. Strategi Mendapatkan Opini WTP Laporan Keuangan Pemda. Jakarta : PPM.

Tukunang, Stanly C. F. 2016. Manajemen Aset Daerah Pada Dinas Pendapatan, Pengelolaan Keuangan dan Aset daerah Kabupaten Kepulauan Siau, Tagulandang, Biaro. Program Magister Manajemen Fakultas Ekonomi Dan Bisnis Universitas Sam Ratulangi. Jurnal Emba Vol. 4 No. 2 Juni 2016. ISSN 2303-1174.

Widodo, Joko . 2001. Good Governance (Telaah dan Dimensi Akuntabilitas dan Kontrol Birokrasi Pada Era Desentralisasi dan Otonomi Daerah). Surabaya : Insan Cendekia. Winarno, Budi. 2008. Kebijakan Public Teori Dan Proses. Yogyakarta : Media Pressindo. 